International Research Journal of Management, IT \& Social Sciences
Available online at https://sloap.org/journals/index.php/irjmis/
Vol. 5 No. 4, July 2018, pages: $61 \sim 70$
ISSN: 2395-7492
https://doi.org/10.21744/irjmis.v5n4.264

\title{
Social Role of Economic and Financial Management in Ecuadorian Universities
}

\begin{abstract}
CrossMark
Monica Murillo Mora ${ }^{a}$

Maricela Reyes Espinosa ${ }^{\text {b }}$

Antonio Vaquez Perez ${ }^{c}$
\end{abstract}

Article history:

Received: 20 February 2018

Revised: 25 June 2018

Approved: 12 July 2018

Published: 25 July 2018

Keywords:

Teaching;

Research;

University;

Economic Crisis;

Administrative Management;

\section{Abstract}

The research analyzes the process of emergence and development of the sciences related to economic and financial management worldwide and in Ecuador and highlights the social role of universities in terms of ensuring the new system of financial administration developed by the country, shown the model of interrelation between the three main actors in the Ecuadorian economy where universities have an important role in the economic and financial management linked to the state and the activities that take place in the academy are present, be it teaching or research. The objective of the work lies in knowing the role of Ecuadorian universities in the economic and financial management, the method used in the study was the literature review.

2395-7492@ Copyright 2018. The Author. This is an open-access article under the CC BY-SA license (https://creativecommons.org/licenses/by-sa/4.0/) All rights reserved.

\section{Author correspondence:}

Mónica Murillo Mora,

Associate Professor and Financial Director

Faculty of Administrative and Economic Sciences, Professor added Universidad Técnica de Manabí,

Email address: mmurillo@utm.edu.ec

\section{Introduction}

It can be said that financial economic management as an activity exists from the first moment that money is used as a measure of value and an instrument of change of any type of transaction. From very remote times, obtaining economic benefit has been of great importance for man, as a means of guaranteeing their subsistence and improving their quality of life. Any type of economic activity, whether of a commercial nature or of providing services, is immersed in this process of financial activity [1].

Finance was considered for a long time as part of the economy; it emerged as an independent field of study at the beginning of the 20th century [1]. That is why it is said that it is a relatively new field of study. The knowledge obtained from the economic crises and the important technological advances helped their evolution and during the process of analysis and management of them, techniques and tools were created that have become valuable information tools for decision making that must face the Financial Administrator [2].

\footnotetext{
a Master in Accounting and Auditing, Aspiring Ph.D., Universidad Tecnica de Manabi, Portoviejo Ecuador

${ }^{\mathrm{b}}$ Faculty of Accounting and Finance, Titular teacher. Doctor in Economic Sciences, University of Havana

${ }^{c}$ Master of Professor hired, Construction Engineering career, Universidad Tecnica de Manabi, Portoviejo Ecuador
} 
Interest in the financial function became critical when it was crucial to generate, organize, plan and distribute the necessary resources to keep the production and sales subsystems in motion, and when the accounting routines for information and analysis, in monetary terms, of the whole of transactions and activities of the company were insufficient [3].

The rapid development of technological innovations and new industries since the early twentieth century, implied the need for more funds, promoting the study of finance to highlight the liquidity and financing of companies. The focus was more on external functioning than on internal administration. Then the interest in the values intensified, especially the common actions, turning the investment banker into a figure of special importance for the study of the corporate finances of the period [4].

Currently, it can be said that the object of study of Financial Economics focuses on financial decisions, both investment and financing. The American normative school states that the functions of the financial management of the company, revolve around obtaining funds and their use and consist of giving a rational and adequate response to a series of questions: What is the total volume of assets What should be invested in each period and at what rate should this volume grow? What kind of assets should the company acquire? Y; What sources of financing should the company use and what should be the composition of that liability? [4].

This normative attitude establishes, in the first place, the rules so that the decisions made by the managers based on these rules are optimal for achieving the objective set by the company. On the contrary, the positive attitude consists in the performance of the financial directors to subsequently establish the rules of action.

Currently, an educational program that does not have a strategic planning, either by stages, by years, by levels, is not conceived. Everything depends on the financial economic management and in many cases, it can be calculated and known what it costs. the education of a person from the beginning of the educational process until it ends, with their aspirations in the third level or university.

Many researchers have devoted time to financial economic management analyzes in public entities where universities are integrated as an essential element for the development of knowledge.

The objective of the work is to expose the process of emergence and development of the sciences related to economic and financial management, emphasizing its social role in the management of universities.

\section{Research Methods}

From an exploratory study through the use of different bibliographies it was possible to know how the economic and financial management of the universities behaves, as well as allowing to assess how it has evolved in time to the present time, the deductive method was used to conclude the paper of universities in financial economic management tables and Figures are presented center, as shown below and cited in the manuscript.

\section{Results and Analysis}

\section{Periods of development of financial economic management}

Finances are considered as a historical-economic category because they are located in space and time and because they take place within the framework of monetary-mercantile relations. They are also a category of value because they are linked to the movement of value in its monetary form with the obtaining, employment and creation of monetary funds [5].

We can differentiate mainly three periods of development of finances, which are listed below [4]:

\section{The descriptive vision of business finances until World War II.}

In the nineteenth century economic theory, as an academic discipline, considerably advanced, emerging the socalled classical model of the hand of Adam Smith in his book "The Wealth of Nations" of 1776. From there followed other British economists such as Malthus, Mill or David Ricardo, Walras, Pareto, Wicksell, and Marshall. Until the beginning of the 19th century, in the area of finance, financial managers were dedicated to keeping accounting books or controlling bookkeeping, and their main task was to seek financing when necessary [4].

By this time the industrial revolution arises in England due to a series of changes in its economy, a phenomenon that begins to spread rapidly throughout Europe and America, giving rise to a group of important innovations. 
As a result, the company expands, mergers take place, for which large issues of shares and obligations are necessary, and special attention is paid to the financial markets and the issuance of loans, in which a spectacular boom is observed [4].

At the beginning of the twentieth century and finance was an external need to the company, only referred to the instruments and procedures of the Capital Market, this begins to change when to improve the situation of entrepreneurs, there are numerous mergers of companies of different importance, which arouses a great interest to have organized information that allows knowing the situation of the company at a given time, this is how the Financial Statements or Balances are born, and the publication of financial information is generalized as a result of the legal requirements [2]

In the 20s, companies needed more funds, they needed a lot of liquidity, and to achieve it they focused on External Financing, which is obtained through investment in shares [2].

In 1929 the economy is immersed in an international crisis. The situation of the New York Stock Exchange was chaotic and the Economic Policy carried out contributed to aggravating the crises, the North American and British financial groups were confronted, there was a rise in the American interest rates that led to the paralysis of the loans abroad, which produced an economic aggravation in the countries that had received these loans [4].

In a scenario like this, companies had problems with financing, bankruptcies, and liquidations. This situation forced to focus the study of finances on the defensive aspects of survival, the preservation of liquidity, bankruptcies, liquidations, and reorganizations [4].

During the crisis, studies were conducted from the legal point of view with the intention that the shareholder and the investor had more information about the economic situation of the company: financing, liquidity, solvency, profitability. It can be affirmed that in this situation the figure of state interventionism appears [4].

In 1936, at the bottom of the Great Depression, "The General Theory of Employment, Interest, and Money" appeared, by John Maynard Keynes, which described a new way of focusing the economy in terms of helping states to mitigate Worst ravages of economic cycles through monetary and fiscal policy [4].

In the early years of the 1940s, Finance followed a traditional approach that had developed over the previous decades. The manager continues with his work, a low-risk policy predominates, which supposed a debt and the liquidity and the solvency prevail. However, in this period begin to germinate the outbreaks of the modern financial concept of the company [4].

In the decade of the '40, the study of cash movement intensified and a technique for cash management emerged, which was cash flow and planning and control within the company itself. Then begins the study and management of finance within the company [2].

\section{From the mid-forties to the foundation of the modern theory of business finance [1]}

After the war, they begin to study the developments of the Operative Investigation and the Computer science applied to the company. In the mid-1950s, planning, control and, with it, the implementation of budgets and capital and treasury controls became important. New methods and techniques for selecting capital investment projects led to a framework for the efficient distribution of capital within the company [4].

Of this time is the work of Professor Erich Schneider Investment and Interest of 1944. In his work, the professor highlights an idea currently in force: an investment is defined by its current collection and payment [4].

In the decade '50 and '60 the financial manager assumes new responsibilities and intervenes in new problems: the administration of the set of resources invested in assets and their allocation in each asset, the determination of the value of the company, determine the capital structure and the dividend policy. Here come a number of models that help financial decision-making and the evolution of finances [2].

Subsequently, complex information systems applied to finance appeared, which made it possible to carry out more disciplined and profitable financial analyzes. The electronic age profoundly affected the means used by companies to carry out their banking operations, pay their bills, collect the money owed to them, transfer cash, determine financial strategies, manage foreign exchange risk, etc. Valuation models were devised to be used in financial decision making, in which the company has a large expansion and the foundations of current finances are established [4].

In this period of prosperity, the objectives that prevail are those of profitability, growth and international diversification, against the solvency and liquidity objectives of the previous period. The techniques of operative research and computerization will also be extended, not only for large companies and the modern Financial Theory will be cemented, where the development of Portfolio Theory or Markowitz Portfolio Selection Theory (1960) can be pointed out as an example. of the Financial Assets Equilibrium Model, which is one of the core elements of modern finance [4].

Mora, M. M., Espinosa, M. R., \& Perez, A. V. (2018). Social role of economic and financial management in Ecuadorian universities. International Research Journal of Management, IT and Social Sciences, 5(4), 61-70. https://doi.org/10.21744/irjmis.v5n4.264 
In the 1970s, the pricing model of Sharpe's capital assets began to be applied to evaluate financial assets [6]. The model implied that part of the company's risk was not important for the company's investors since it could be diluted in the portfolios of the shares in its possession. It also caused attention to be focused on the imperfections of the market when judging the selection of assets made by the company, financing, and dividends.

\section{Expansion and deepening of finances to this day}

From the 70s to the present, studies on the science of the economic and financial management of companies have expanded and deepened significantly. Emerging new lines of research such as The theory of valuation of options; The theory of valuation by arbitration and; The theory of agency [4].

The Theory of option valuation had its origin with the investigations of Black and Sholes in 1973, for the relative evaluation of financial rights. The existence of an options market allows the investor to establish a protected position without risks, buying shares and at the same time establishing options on shares. Inefficient financial markets, the yield produced by a position of this type must be a risk-free rate. If this is true, it would be possible to establish exact formulas to evaluate different types of options [4].

In this walk through the history of financial decisions, we will assume that the objective of financial economic management is to maximize the market value of the company. This is an objective pointed out by a large number of studies and researchers such as Bierman and Smidt, Robichek, Mao, Beranek, Weston and Brigham, Pike and Dobbins, Suárez [4].

In the 1980s, important advances were made in the valuation of companies in a world where uncertainty reigns. Increasing attention has been paid to the effect that market imperfections have on value. The economic information allows a better understanding of the behavior of the financial documents in the market. The notion of an incomplete market, where the wishes of investors of particular types of securities are not satisfied, places the company in the role of carrying out the commercialization of special types of financial rights [4].

Interest in the internationalization of financial phenomena and decisions is accentuated, giving rise to a multitude of studies on aspects such as political risk and the risk of exchange rate variability of the currencies in which International Economic and Financial Management operates. [4].

In the 1990s, finance played a vital and strategic role in companies. The finance manager has become an active part: the generation of wealth. In order to determine if it generates wealth, it must be known who contributes the capital that the company requires to have profits. This becomes the basis for the cost of the opportunity, with respect to which the product, investment, and operating decisions will be judged [4].

Leland (1994) in the search for the optimal financial structure discovers that the value of the debt and the optical indebtedness are explicitly connected to the company's risk, taxes, bankruptcy costs, the risk-free interest rate and the payout ratios.

The valuation theory of companies seemed stagnant, at least since the seventies and only recently has gained a remarkable momentum under the influence of authors such as Cornell (1993), Copeland, Koller and Murrin (1995) and Damodaran (1996). O Fernández (1999) and Amat (1999) in Spain [4].

In the nineties, the theory and practice of business valuation continued to be centered around very classical and somewhat obsolete methods, such as static or balance sheet approaches and mixed models such as German and AngloSaxon. These methods seem overcome today, even admitting their virtuality and usefulness for the valuation in small businesses.

Another reality of the 90s is the globalization of finance. As global financial markets are increasingly integrated, the finance manager must seek the best price for national borders and often with foreign exchange and other barriers.

External factors influence the financial manager more every day: deregulation of financial services, competition between capital providers and financial service providers, volatility of interest rates and inflation, variability of currency exchange rates, reforms taxes, global economic uncertainty, external financing problems, speculative excesses and the ethical problems of certain financial businesses [4].

Currently, the methodology based on the discount of cash flows seems indisputable and is the most consistent and solid in terms of its theoretical foundations. For this line, Martín Marín and Trujillo Ponce (2000) have tried to progress in their work "Manual of valuation of companies". Regarding the issue of new economy or virtual economy companies related to the Internet, these authors in their own words prefer to give themselves a waiting period before tackling such a thorny issue. 
3.1 Economic Financial Management in Ecuador

Subsection should be written without a bold type. The result and analysis are presented by present form. Please avoid too many paragraphs in this section.

Ecuador has been affected by regional crises and bad financial practices by the entities, for not having a sustainable planning, harming not only the financial sector but the country has lived in the crisis during the years 1999-2000, whose effects are felt up to the present, concluding with the process of dollarization of the national currency [7].

Since 2000, the slow recovery of loans to customers, as well as the difficulty of attracting private investments to increase the assets of the mutual has become a problem. One of the causes of this problem is the lack of adequate planning and financial control [7].

Considering the difficulties analyzed previously, on January 2, 2008, the Government of the Republic of Ecuador implemented the production of the First Version of the New Financial Administration System (eSIGEF). The implemented products and the great modernizing changes achieved in the public financial economic management of the Government of Ecuador, account for a process of sustained institutional strengthening, an important ordering of accounts on the management of public resources, a standardization in the management of the information, a technicalcultural change in the thousands of users of the System, among many of the achievements of this change [8].

As of January 2009, the Ministry of Finance assumed the institutionalization of the e-SIGEF project, establishing strategies for its operation and strengthening of its technological infrastructure in order to ensure the sustainability and uninterrupted continuity of the activities. The definition of the conceptual model of the new system reflects the result of the detailed review of all the processes included in the subsystems and modules that compose it to adapt them to the needs imposed by the Public Administration Management Model and the characteristics of the economy of the Country, which implies a structural change aimed at correcting the weaknesses and problems of the current system, simplifying the processes and relations of the Ministry of Finance and the institutions, and facilitating the registration and control of the generation and use of public resources, in terms of transparency, efficiency, effectiveness and economy [8].

Through the process seeks to integrate the set of activities that make up the economic and financial management of institutions, seeks to generate, process and provide timely and relevant information to support the decision making of the administrators of entities and government authorities, as well as the transparency in the administration of public funds [9].

The components of the Public Financial Administration in Ecuador are Budget; Accounting; Treasury; Debt management; Management of human resources; Management of goods and services and; Project Management [9].

A new approach from the technological point of view was required. The old conception of monolithic and rigid systems that allowed to automate processes, has evolved and has been transformed into a new paradigm that is redefining the role of Information and Communication Technologies within Public Administration, which enables an improvement of efficiency in the administrative processes, greater transparency and a progressive simplification of them.

The use of Web-based technology has grown as a phenomenon that efficiently communicates people and institutions and whose application is changing the way we think, work and communicate. Like any private business process in the world, business processes and public services and the same institutions need to go through this process of transformation and evolution in order to take advantage of the benefits of using this technology and ensure their permanence in the time [8].

The Ecuadorian system is being constituted in a management system, allowing each user system user, in compliance with their responsibilities assigned in the procedures related to budget transactions, accounting, payment of obligations, purchase of goods and others, register them once and in real time. The registry is made in a single database with a direct connection to the user entities of the central system, in order to have timely information.

\subsection{Economic Financial Management in Ecuadorian Universities}

Cooperation for sustainable development that enhances the internationalization of higher education, promoter, and manager of organizational change, is important to achieve high educational standards and move towards competitive and contextualized educational models that are able to assimilate uncritically the best experiences, respecting the culture and identity of the peoples. In the case of Ecuador, it is essential to contribute to the National Plan for Good Living and to transform the productive matrix [10]

Through Financial Management, decisions are made regarding the expansion of the business, types of securities that must be issued to finance growth, the terms of credit on which customers can make their purchases, the number

Mora, M. M., Espinosa, M. R., \& Perez, A. V. (2018). Social role of economic and financial management in Ecuadorian universities. International Research Journal of Management, IT and Social Sciences, 5(4), 61-70. https://doi.org/10.21744/irjmis.v5n4.264 
of inventories that must be maintained, the cash that must be available, analysis of mergers, profits to be reinvested instead of being paid as dividends and other functions [11].

On the other hand, the universities are the structures of the fabric of society that due to the complexity of the relationships that come into play, the diversity in terms of its social composition and the type of activities that take place on a daily basis, it could be said that it most resembles a large city and in this context the level of decisions in the field of financial administration takes on extraordinary importance.

The concentration in the institutional crisis in Ecuador for several decades was fatal for the university and this was due to a plurality of factors, some already evident at the beginning of the nineties and others that gained a lot of weight during the course of the same decade.

The institutional crisis was and has been for at least two centuries, the weakest link in the public university because the scientific and pedagogical autonomy of the university is based on the financial dependence of the State. This dependence was not problematic while the university and its services were unequivocally understood as a public good that, therefore, corresponded to the State to ensure similarly to what happens with the judicial system, where the independence of the courts is not put under discussion due to the fact that they are financed by the State. However, contrary to what happens with justice, the State decided to reduce its political commitment to universities and education in general, making it a good, that being public, does not have to be insured by the State, so the public university automatically entered into institutional crisis [11].

Currently Ecuadorian and contrary to the conservative and orthodox spirit of the neoliberal economy, which raised within its recipe the privatization of public companies, the Government of the Citizen Revolution returned in its just measure, an important role to public companies as tools for the provision of services, the management of strategic sectors, the sustainable use of natural resources and public goods and other activities that must be promoted by the State, to ensure its development plan and a new regime of accumulation [13].

The Constitution of the Republic of Ecuador [14] and the National Plan for Good Living 2013-2017 [15], recognizes public companies as agents of productive transformation and highlight their role in securing the sovereignty and efficiency of the management in strategic sectors. Through them, it is not only intended to generate extractive income, but also to promote the productive reconversion towards the knowledge society.

Public companies are key in the development of basic industries to generate employment and productive linkages with the national private sector. Betting on adequate and necessary public companies means rescuing the public and promoting management models where the logic of capital does not prevail. Therefore, public companies must be rational, transparent, efficient and profitable and of quality, they must also contribute to social control. These elements are not only management expectations, but principles and legal mandates that are embodied in the Organic Law of Public Enterprises [13].

In the National Plan for Good Living 2013-2017 [15], the planning guidelines for public companies have been established. Additionally, through the directories of these, the emphasis has been placed on strategic direction, principles of corporate governance, guidelines for efficient financial economic management and for organizational development; focusing fundamentally on the strategy of transforming the productive matrix.

The economic and financial management of the University of the current times in Ecuador is aimed at supporting an education in the way of sustainable development, which means a university that is more relevant to society.

The radical change from a conservative culture to a culture open to innovation and entrepreneurship [15].

To achieve the success of the new Financial Administration System in Ecuador, it is necessary to strengthen the triple helix scheme. This formula is given in the existence of three fundamental actors in the economy that are taxed functions and activities.

Figure 1 shows the model of the interrelation between the three main actors in the Ecuadorian economy, shaped towards the change of the productive matrix and sustainable development. 


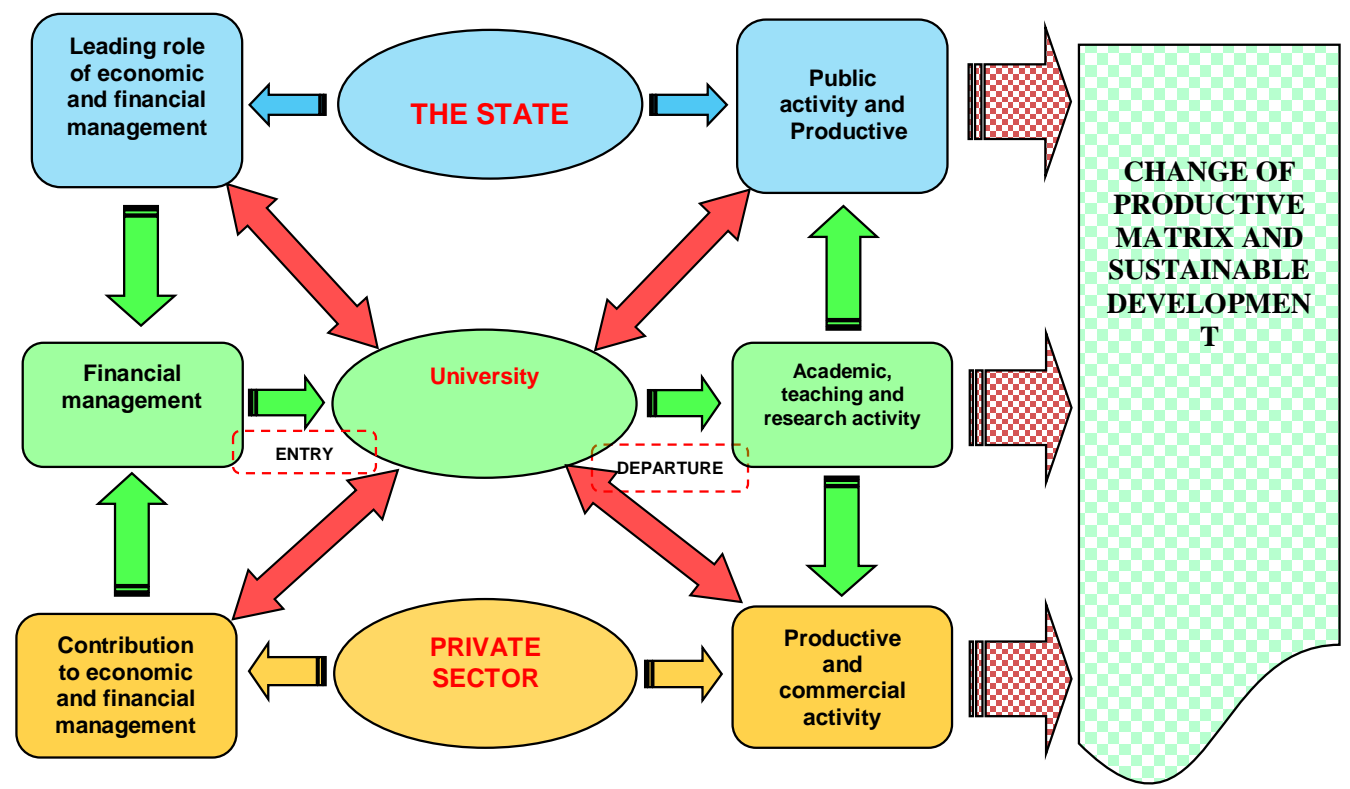

Figure 1. Model of interrelation that exists between the three main actors in the Ecuadorian economy

The university with the academy is among the fundamental actors in economic development in alliance with the State (public and productive activity) and the private sector (productive and commercial activity). In this scenario, universities generate ideas and tools for the change of social culture, which will be useful in the field of public, productive and commercial activities while receiving material support for financial management and administration.

The state proposes and approves policies and laws that regulate the product management and financial administration. The private sector contributes investment, as well as productive and commercial activity [16]. This relationship is the key to change the production matrix that has been proposed by the country, on the basis of achieving sustainable development.

When talking about quality in economic and financial management, it refers to ensuring that the organization is efficient to be able to provide consistent products and that for this purpose it must plan, control, build insurance programs and improve quality, aspects that are directly related to university strategic planning, and other management tools such as the design of the organizational structure, the university budget, and internal control.

The book "The Best University in the World" [15], mentions with great emphasis on the importance of strategic planning in Universities as an essential tool for a new university management.

For the Ecuadorian universities, the financial administration represents ensuring a fully inclusive and democratic process, which assumes that science is not the property of an elite, nor of what was called the aristocracy of intelligence, but of the whole society, even more so of the humanity.

The Technical University of Manabí as a public institution of higher education aspires to be located in a place of reference in support of the change of the productive matrix proposed by the Ecuadorian State, generating the ideas and tools that allow a conservative and traditionalist culture to travel, towards a novel culture open to innovation and entrepreneurship, for which it will have to be located at the top of public institutions depending on the management and financial management system. The doctoral thesis entitled "The process approach in the economic and financial management of Ecuadorian public universities", is a further effort to achieve the objectives set.

\section{Conclusion}

The paper analyzes the process of emergence and development of the sciences related to economic and financial management worldwide and in Ecuador and highlights the social role of universities in terms of ensuring the new financial management system developed by the country. from the year 2008.

Through research, the role of the university as one of the main actors of the Ecuadorian economy is demonstrated, based on the financial administration system assumed by the country..

Mora, M. M., Espinosa, M. R., \& Perez, A. V. (2018). Social role of economic and financial management in Ecuadorian universities. International Research Journal of Management, IT and Social Sciences, 5(4), 61-70. https://doi.org/10.21744/irjmis.v5n4.264 
Conflict of interest statement and funding sources

The authors declared that they have no competing interest. The study was financed by personal funding.

Statement of authorship

The authors have a responsibility for the conception and design of the study. The authors have approved the final article.

Acknowledgments

We thank the University for the support it has given me to develop the research presented. 
References

1. Del Valle, and Schemel, M. (2011). Desarrollo y Evolución de las finanzas. Revista digital Acta Odontológica Venezolana. Obtenido de http://www.actaodontologica.com/ediciones/2011/1/art19.asp. Consultado agosto 2015

2. Barrientos, D. M. (2009). Manual de Gestión Financiera. Centro Cultural de la Estación Mapocho. Obtenido de Curso de Gestión Financiera en una Institución www.hacienda.go.cr/cifh/sidovih/cursos/material_de_apoyo-F-CFH/1MaterialdeapoyocursosCIFH/12ProgramaFormacRectoriaFinanciera/ManualGestionFinanc.pdf

3. UDIMA. (2009). Evolución histórica de la función financiera de las organizaciones. Introducción a la Organización de Empresas / Unidad didáctica 4. El sistema de financiación de la empresa. Obtenido de adeudima.com: http://www.adeudima.com/?page_i. Consultado en septiembre 2017

4. Arlenis, G. (2005). Reseña histórica de la evolución de la ciencia financiera. Página web, monografias.com, (Consultado 09- 2015) www.monografias.com/trabajos20/finanzas/finanzas.shtml, 2005.

5. Mariño, G. y. (2009). La administración financiera: una utopía en las microempresas. Criterio Libre. Universidad Libre de Colombia, VII $\quad$ (11). www.unilibre.edu.co/CriterioLibre/images/revistas/11/CriterioLibre11art05.pdf.

6. Alvarellos, L. (2014). Modelos de valoración de activos de capital. Trabajo de fin de grado presentado en la Facultad de Economía y Empresa de la Universidad de la Coruña para la obtención del Grado en Ciencias Empresariales Facultad de Economía y Empresa. España.

7. Toscano, S. (2010). El sistema financiero ecuatoriano. Superintendencia de Bancos. Obtenido de bibdigital.epn.edu.ec/bitstream/15000/2573/1/CD-0367.pdf.Ecuador. Ministerio de Finanzas del Ecuador. (2015). Fortalecimiento del Sistema de Administración Financiera del Sector Público Ecuatoriano -e-SIGEF Fase III. Obtenido de http://www.finanzas.gob.ec/wpcontent/uploads/downloads/2015/02/fortalecimiento-del-sistema-deadministraci\%c3\%93n-financiera-del-sector-p\%c3\%9ablico-ecuatoriano.pdf.

8. Hugo, N. (2010). Modernización del Sistema de Administración Financiera del Estado. Página web, inSlideShare, (Consultado 09- 2015) http://es.slideshare.net/fundacionmetis/modernizacion-del-sistema-de-administracinfinanciera-del-estado-ecuador.

9. Medina Pogo, J. L. (2012). Modelo de Gestión Administrativa para el Gobierno de la Parroquia de Yaruquí, Cantón Quito, Provincia de Pichincha.

10. Briones, V., Entenza, N., Gámez, M., \& Cedeño, M. (2016). Management Model for University Cooperation at the Universidad Técnica De Manabí, Ecuador. International Research Journal Of Management, IT \& Social Sciences (IRJMIS), 3(9), 1 - 7. doi:10.21744/irjmis.v3i9.156

11. Boaventura, S., (2007) La Universidad en el Siglo XXI. Para una reforma democrática y emancipatoria de la universidad. CIDES-UMSA. Postgrado en Ciencias del Desarrollo. Bolivia. www.cides.edu.bo / Email: cides@e20ntelnet.bo 2007. Colección Universidad. Cuarta edición en castellano. ISBN: 978-99954-1-078-0. D.L.: 4-1-12 97-07((Consultado 08-2015) www.cides.edu.bo).

12. Secretaria Nacional de Planificación y Desarrollo. (2015, septiembre). Empresas Públicas y Planificación. Su rol en la transformación social y productiva. Obtenido de www.planificacion.gob.ec. ISBN: 978-9942-07-503-1 SENPLADES. Ecuador.

13. Constitución de la República del Ecuador, Registro Oficial 449, (2008, 20 de octubre). Asamblea Constituyente. Modificación: 13-jul-2011. Última modificación: 21-dic.-2015.

14. Secretaría Nacional de Planificación y Desarrollo. (2012, septiembre). Plan Nacional del Buen Vivir 2013-2017 Obtenido de www.planificacion.gob.ec. PNBV SENPLADES.

15. Andrade, J. (2015). Sobre la educación para el desarrollo sostenible y sobre el sistema educativo. Revista la Otra. Edición especial No 69. Editorial Unimasa del Ecuador S.A., 17.

Mora, M. M., Espinosa, M. R., \& Perez, A. V. (2018). Social role of economic and financial management in Ecuadorian universities. International Research Journal of Management, IT and Social Sciences, 5(4), 61-70. https://doi.org/10.21744/irjmis.v5n4.264 


\section{Biography of Authors}

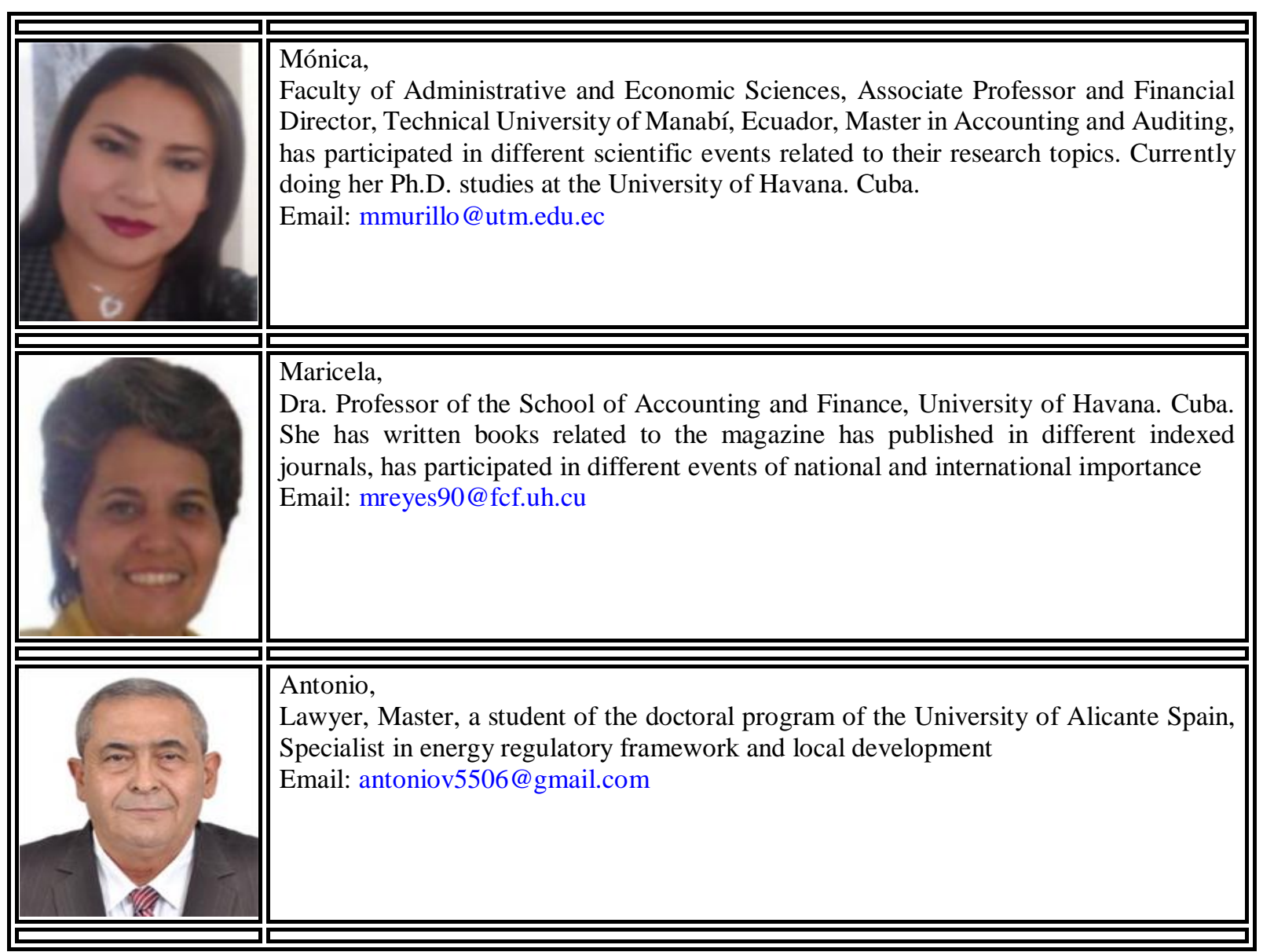

